ISSN 1991- 8690

website :http:// jsci.utq.edu.iq

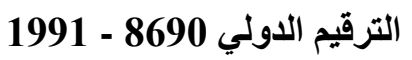

Email: utjsci@utq.edu.iq

\title{
Isolation And Identification Of Some Pathogenic Bacteria And Fungi From Restaurantes And Meat Shop's In Al-Samawa City
}

\author{
${ }^{(1)}$ Hasanain Yaseen Marzoq \\ ${ }^{(2)}$ Ziad Fadhil Saeed \\ ${ }^{(3)}$ Rima Nehmatullah Hasan
}

${ }^{(1,3)}$ Assist. Lect., Foundation of Technical Education, Technical institute of AL-Samawa - Department of Community Health.

${ }^{(2)}$ Assist. Lect., Foundation of Technical Education, Technical institute of AL-Samawa - Department of Nursing.

\begin{abstract}
$\underline{\text { Abstract }}$
The present study include isolation and identification of some pathogenic fungi and bacteria from restaurant and meat shop's in AL-Samawa city by taking samples from 15 restaurants and 15 meat shop's, choose randomly with three replicates for each sample on solid culture medium Potato's Dextrose Agar (PDA) for fungi and Nutrient Agar for bacteria. The results showed several fungal and bacterial species were isolated from these places, for restaurants fungal species were: Rhizopus stolanifer, Penicillium notatum, Fusarium oxysporum, Alternaria alternata, Aspergillus niger, Rhizoctonia solani, Cladosporium sp. and Aspergillus flavus, with percentage of frequency which has $(21.78,10.89,7.92,8.91,18.81,7.92,6.93$ and 16.83$) \%$ respectively, while the bacterial species were: Bacillus cereus, Clostridium botulinum , Escherichia coli, Salmonella typhi, Shigella dysenteriae, Staphylococcus aureus and Lactobacillus subtilus (12.16, 9.45, 21.62, 18.91, 16.21, 12.16 and 9.45)\% respectively. From meat shop's the isolated fungal species were: Aspergillus niger, Penicillium notatum, Aspergillus flavus, Rhizopus stolanifer and Cladosporium sp. (23.91, 16.30, 19.56, 28.26 and 11.95)\% respectively, while the isolated bacterial species were: Salmonella typhi, Staphylococcus aureus, Lactobacillus subtilus, Pseudomonas aeruginosa, Escherichia coli and Clostridium perfringens $(15.87,19.04,17.46,9.52,23.80$ and 14.28)\% respectively.
\end{abstract}

الخلاصة

تضمنت هذه الدراسة عزل وتتخيص بعض الفطريات والبكتريا من اجواء المطاعم ومحال بيع اللحوم داخل مدينة السماوة وذلك من

خلال أخذ عينات من 15 مطعم و 15 محل لبيع اللحوم، اختيرت بصورة عشوائية وبثلاث مكررات لكل عينة ثم العزل على الوسط الغذائي الصلب البطاطا دكستروز بالنسبة للفطريات وعلى الوسط المغذي الصلب بالنسبة للبكتريا. بينت النتائج عزل وتتخيص انواع مختلفة من

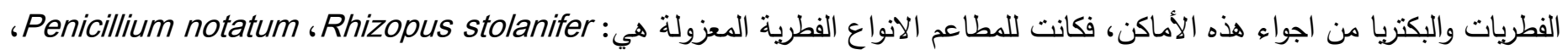
و Cladosporium sp. ‘Rhizoctonia solani ،Aspergillus niger ،Alternaria alternata ،Fusarium notatum Aspergillus flavus الانواع البكتيرية المعزولة هي: Escherichia coli ، Clostridium botulinum Bacillus cereus، Shigella ، Salmonella typhi ، 
(Lactobacillus subtilus Staphylococcus aureus ddysenteriae 16.21، 12.16 و 9.45)\% على التوالي، وبالنسبة لمحال بيع اللحوم الانواع الفطرية المعزولة هي:Aspergillus niger، (Cladosporium sp. Rhizopus stolanifer Aspergillus flavus ،notatum وكانت نسب التزدد (23.91، 16.30، 16.56، 19.56،

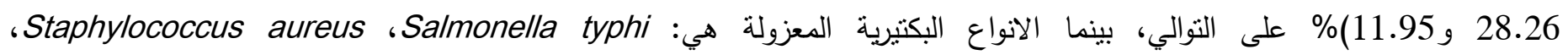
، Escherichia coli ، Pseudomonas aeruginosa ،Lactobacillus subtilus

$$
\text { 17.46، 9.52، } 23.80 \text { و 14.28)\% على التوالي. }
$$

\section{Introduction}

Microorganisms exist everywhere, in the air, water and soil, animals and even humans, some of which cause spoilage to the food. There are three types of microorganisms that can contaminate food and cause foodborne illness: bacteria, viruses and parasites. Either fungi they cause food spoilage, but do not cause disease through food (but toxins causing diseases). When microorganisms exist in the food and consumed by customers in restaurants may occur illnesses and food poisoning, and common symptoms of foodborne illness are: diarrhea, vomiting, fever and abdominal pain [8].

Most fungi and bacteria produced toxins that cause disease [8]. From fungi that cause food spoilage the fungus Rhizopus stolanifer that capable to cause opportunistic infections for human [23]. Penicillium notatum consider the main causes of food spoilage, and produced mycotoxins [3]. While the fungus Fusarium oxysporum produce aflatoxin as Fumonism and Zearalenone that cause food spoilage [11]. Either the fungus Alternaria alternata cause diseases on over 380 host species and consider opportunistic pathogen in addition cause food spoilage by produced toxin know alternariol [7]. Also Aspergillus niger able to produce mycotoxins that cause seeds spoilage and human diseases [15]. While Rhizoctonia solani cause crown rot infection on beet and produced spores that cause food spoilage [19]. In addition Aspergillus flavus produced aflatoxin that cause human, animal diseases and cause food spoilage [10]. Either Cladosporium sp. spores transport to other plants and cause spoilage, this fungus exist in cooking, bathrooms, fabrics, or this fungus found in refrigerated food [16].
Some of bacteria produce toxins, but not all the toxins can be eliminated by cooking [8]. From these bacteria that cause foodborne illness Bacillus cereus which cause foodborne illnesses which occur due to survival of the bacterial endospores when food is improperly cooked [17]. Also Clostridium botulinum that causing botulism poisoning can occur due to improperly preserved or canned, low-acid food that was not processed using correct preservation times and/or pressure [12]. In addition Most Escherichia coli strains are harmless, but some serotypes can cause serious food poisoning in humans [20]. While the bacterium Salmonella typhi is closely related to the Escherichia genus (because it's one of enterbactericiae genus). They cause illnesses such as typhoid fever, paratyphoid fever. Infection usually occurs when a person ingests foods that contain a high concentration of the bacteria [17]. Shigella dysenteriae which cause dysenteric diarrhea worldwide via ingestion (fecal-oral contamination); depending on age and condition of the host, less than 100 bacterial cells can be enough to cause an infection [22]. Also the bacterium Staphylococcus aureus is responsible for food poisoning through the production of an enterotoxin, and pathogenicity is also associated with coagulase positivity [21]. Lactobacillus subtilus species have been associated with dental caries. Lactobacillus subtilus count in saliva has been used as a "caries test" for many years. Lactobacillus subtilus characteristically cause existing carious lesions to progress, especially those in coronal caries [18]. While the bacterium Pseudomonas aeruginosa can cause food spoilage. Notable examples include dairy spoilage by $P$. fragilis, mustiness in eggs caused by $P$. taetrolens 
and $P$. mudicolens, and $P$. lundensis, which causes spoilage of milk, cheese, meat, and fish [14]. Either the bacterium Clostridium perfringens is the third most common cause of foodborne illness by produce enterotoxin (CPE) is heat-labile (inactivated at $74{ }^{\circ} \mathrm{C}$ ) and can be detected in contaminated food. Since $C$. perfringens forms spores that can withstand cooking temperatures, if let stand for long enough, germination ensues and infective bacterial colonies develop [17].

\section{Aim of Study}

Identify some pathogenic fungi and bacteria which cause food poisoning in most restaurants and meat shop's in AL-Samawa city.

\section{Materials \& Methods}

\section{1-Solutions \& Media Preparation}

- Fungi:

\section{1-Lactophenol-Cotton Blue Tincture:}

Prepared according to the method [6].

\section{2- Potato's Dextrose Agar (PDA):}

Prepared according to the manufacturer's specifications (HiMedia Laboratories Pvt. Ltd. India).

\section{- Bacteria:}

\section{1-Gram Stain:}

Prepared according to the manufacturer's specifications [13], and used this solution for study the morphological characteristics of bacterial cells under microscope.

\section{2-Physological Buffer Saline:}

Prepared according to method [2]. Used this solution for dilution.

\section{3-Catalase Test Reagent:}

Prepared according to method [13]. Used for discover about bacterial catalase production.

\section{4-Oxidase Test Reagent:}

Prepared according to method [5]. Used this solution for discovering about bacterial oxidase production.

\section{5-Nutrient Agar Medium:}

Prepared according to method [4]. Used for isolate aerobic and anaerobic bacteria.

\section{6-Macconky Agar Medium:}

Prepared according to method [4], and used for differentiation between Enterobacillus bacteria which lactose fermented and non-fermented [5].

\section{7-Blood Agar Medium:}

Prepared according to method [5]. Used for culturing gram positive bacteria and discovered hemolytic ability of bacterial.

\section{8-Motility Medium:}

Prepared according to method [13]. Used this medium for discovering the bacterial motility.

\section{2-Isolation}

\section{- Fungi:}

Fungi isolated by taking samples (by exposure the dishes to air) from 15 restaurants and 15 meat shop's in AL-Samawa city (three replicates for each locational sample), by prepare solid medium of Potato's Dextrose Agar (PDA). Then Petri dish cover was opened and exposed to the air in restaurants and meat shop's weather for period of one hour and then cover is closed, and then put it in incubator with temperature of $25^{\circ} \mathrm{C}$ for one week.

\section{- Bacteria:}

Bacteria isolated by taking samples (by exposure the dishes to air) from 15 restaurants and 15 meat shop's in AL-Samawa city [six replicates for each locational sample (three for aerobic bacteria and other three for anaerobic bacteria)], by prepared Petri dishes contain on nutrient agar, and then left the dishes to cool in room temperature. Then Petri dish cover was opened and exposed to the restaurants and meat shop's for period one hour and then cover is 
closed, and then put it in incubator with temperature of $37{ }^{\circ} \mathrm{C}$ for $24-48$ hour (three dishes put it in anaerobic conditions by used Anaerobic Jar with Gas Pack and three dishes put it in aerobic conditions).

\section{3-Identification}

- Fungi:

\section{1- Morphological Properties:}

Depending on shape, size and color of the colonies.

\section{2- Microscopical Properties:}

Depending on structure, color and shape of mycelium and spores under the microscope according to taxonomic bases and using taxonomic keys from the references that deal with classification and study of fungi [9].

\section{- Bacteria:}

\section{1- Morphological Properties:}

Depending on shape, color, height, texture, diameter and other properties of the colonies after culturing on Blood agar for gram positive bacteria and on Macconky agar for gram negative bacteria.

\section{2- Microscopical Properties:}

Depending on bacterial staining by gram stain and notice the reaction with stain, cells bacterial shape, spores formation and its regulation with each other.

\section{3-Biochemical Tests:}

- Catalase test:

According to method [5].

\section{- Oxidase test:}

According to method [5].

\section{- Motility test:}

By using motility medium according to method [13].
- Blood hemolysis test:

By using blood agar according to method [13].

\section{- Coagulase test:}

According to method [13].

\section{Results \& Discussion}

The results showed isolated and identified several types of pathogenic fungal and bacterial from restaurants and meat shop's atmosphere in AL-Samawa city.

From isolated fungal species are Rhizopus stolanifer and Penicillium notatum that were isolated from restaurants and meat shop's, because it's spores speared rapidly in room temperature [3] [23]. Either Fusarium oxysporum, Alternaria alternata and Rhizoctonia solani were isolated from restaurants, because these fungi exist in soil, and move easily with vegetable, seeds and fruits so it's spores become contaminate for food [11] [7] [19]. Also Aspergillus niger and Aspergillus flavus were isolated from restaurants and meat shop's, because it's spores are widely spread in air, and affect wide range of plants and can grow faster in high and moderate temperature [15] [10]. While Cladosporium sp. was isolated from restaurants and meat shop's, because it's can exist on surface of most moist places [16].

From the isolated bacterial species are Bacillus cereus and Clostridium botulinum which isolated from restaurants, because it's exist in preserved food by unsaved conditions [17] [12]. Also Escherichia coli, Salmonella typhi, Staphylococcus aureus and Lactobacillus subtilus isolated from restaurants and meat shop's, because these bacteria found in meat which cooked with insufficient heat, egg cortex, lettuce, fruits juice and other food [20] [17] [21] [18]. So Shigella dysenteriae was isolated from restaurants, because this bacterium is found in salad, milk and it's productions [22]. While Pseudomonas aeruginosa isolated from meat shop's, because its widely spread in unsterilized water [14]. So Clostridium perfringens isolated from meat shop's, because this bacterium found in insufficient cooked meat [17]. 
Table (1): Isolated fungal species from restaurants and meat shop's

\begin{tabular}{|c|c|c|c|c|c|c|}
\hline \multicolumn{7}{|c|}{ Isolated fungal species } \\
\hline NO. & Restaurants & $\begin{array}{c}\text { Accounts } \\
\text { of } \\
\text { Colonies }\end{array}$ & Per. & Meat shop's & $\begin{array}{c}\text { Accounts } \\
\text { of Colonies }\end{array}$ & Per. \\
\hline 1 & Rhizopus stolanifer & 22 & 21.78 & Rhizopus stolanifer & 26 & 28.26 \\
\hline 2 & Penicillium notatum & 11 & 10.89 & Penicillium notatum & 15 & 16.30 \\
\hline 3 & Fusarium oxysporum & 8 & 7.92 & & - & - \\
\hline 4 & Alternaria alternata & 9 & 8.91 & - & - & - \\
\hline 5 & Aspergillus niger & 19 & 18.81 & Aspergillus niger & 22 & 23.91 \\
\hline 6 & Rhizoctonia solani & 8 & 7.92 & & - & - \\
\hline 7 & Cladosporium sp. & 7 & 6.93 & Cladosporium sp. & 11 & 11.95 \\
\hline 8 & Aspergillus flavus & 17 & 16.83 & Aspergillus flavus & 18 & 19.56 \\
\hline
\end{tabular}

(-): Note to non-existence of fungus.

Table (2): Isolated bacterial species from restaurants and meat shop's

\begin{tabular}{|c|c|c|c|c|c|c|}
\hline \multicolumn{7}{|c|}{ Isolated bacterial species } \\
\hline NO. & Restaurants & $\begin{array}{c}\text { Accounts } \\
\text { of } \\
\text { Colonies }\end{array}$ & Per. & Meat shop's & $\begin{array}{c}\text { Accounts } \\
\text { of } \\
\text { Colonies }\end{array}$ & Per. \\
\hline 1 & Bacillus cereus & 9 & 12.16 & - & - & - \\
\hline 2 & Clostridium botulinum & 7 & 9.45 & - & - & - \\
\hline 3 & Escherichia coli & 16 & 21.62 & Escherichia coli & 15 & 23.80 \\
\hline 4 & Salmonella typhi & 14 & 18.91 & Salmonella typhi & 10 & 15.87 \\
\hline 5 & Shigella dysenteriae & 12 & 16.21 & & - & - \\
\hline 6 & Staphylococcus aureus & 9 & 12.16 & Staphylococcus aureus & 12 & 19.04 \\
\hline 7 & Lactobacillus subtilus & 7 & 9.45 & Lactobacillus subtilus & 11 & 17.46 \\
\hline 8 & - & - & - & Pseudomonas aeruginosa & 6 & 9.52 \\
\hline 9 & - & - & - & Clostridium perfringens & 9 & 14.28 \\
\hline
\end{tabular}

(-): Note to non-existence of bacterium. 


\section{Conclusions}

1- Several types of pathogenic fungi and bacteria were isolated which cause food spoilage.

2- Noticed that all places which collect samples from it had a contaminated atmosphere completely with fungal and bacterial agents.

3- The results showed there are some pathogenic agents present in restaurants atmosphere only like: Fusarium oxysporum, Alternaria alternata, Rhizoctonia solani, Bacillus cereus, Clostridium botulinum and Shigella dysenteriae, and other pathogenic agents found especially in meat shop atmosphere only like: Pseudomonas aeruginosa and Clostridium perfringens.

\section{$\underline{\text { Recommendations }}$}

1- Commitment with health rules that deal with restaurants and shop's cleanly.

2- Proceeding regular medical tests for restaurants and shop's workers.

3- Using the sterilizing and disinfecting agents continuously for restaurants and shop's atmosphere.

4- Regular checking by inspection comity and veterinary hospital to check the safety of food and meat.

\section{$\underline{\text { References }}$}

1. Hocking, A.D. (2006).Advances in Food Mycology (Advances in Experimental Medicine and Biology).

2. Atlas, R.M.; Parks, L.C. and Brown, A.E. (1995). Laboratory manual of experimental microbiology. $1^{\text {st }}$. Mosby-Year Book.

3. Balgrie, B. (2003). Taints and Off-flavours in Food. CRC Press. p. 134.

4. Baron, E.J.O.; Finegold, S.M. and Petrson, L.R. (1994). Bailey and Scott's Diagnostic
Microbiology $9^{\text {th }}$ ed. Mosby. Missouri USA: 389-395.

5. Collee, J.G.; Faser, A.J.; Marmion, B.P. and Simmons, A. (1996). Mackie and McCartney Practical Medical Microbiology. $14^{\text {th }}$ ed., Churchill Livingstone. USA.

6. Ellis, D. H. (1994). Clinical mycology. The human opportunistic mycoses. Gillingham printers Ltd. Australia.

7. Genteno, S. and Calvo, M.A. (2002). Mycotoxins produced by fungi isolated from wine cork stopper. Pakistan. Nut. , 6: 267 269.

8. Hans, P. and Dean, O. (2006). Foodborne Infections and Intoxications.

9. Kirk, P. M.; Cannon, P. F.; David, J. C. and Stalpers, J. A. (2008). Ainsworth \& Bisby's Dictionary of the Fungi, 9th edition. CABI Bioscience.

10. Klich, M.A. (2007). Aspergillus flavus: the major producer of aflatoxin. Molecular Plant Pathology 8(6): 713-22.

11. Leslie, J.F. and Summerell, B.A. (2006). The Fusarium Laboratory manual. (Blackwell Publishing: Iowa, USA).

12. Lew, B. A. and Stewart, A. F. (2010). "A quadruplex real-time PCR assay for rapid detection and differentiation of the Clostridium botulinum toxin genes A, B, E and F". J Med Microbiol 59 (Pt 1): 55-64.

13. MacFaddin, J.F. (2000). Biochemical tests for identification of medical Bacteria. $3^{\text {rd }}$. Lippincott William and Wilkins. USA.

14. Palleroni, J. (2010). "The Pseudomonas Story". Environmental Microbiology 12 (6): 1377-1383.

15. Pel, H.; de Winde, J. and Archer, D. (2007). "Genome sequencing and analysis of the versatile cell factory Aspergillus niger CBS 513.88". Nat Biotechnol 25 (2): 221-31. 
16. Rivas, S. and Thomas, C.M. (2005). Molecular interactions between tomato and the leaf mold pathogen: Cladosporium fulvum. Annual Review of Phytopathology 43: 395-436.

17. Ryan, K.J. and Ray, C.G. (2004). Sherris Medical Microbiology (4th ed.). McGraw Hill.

18. Tasli, L.; Mat, C. and De Simone, H. (2006). "Lactobacilli lozenges in the management of oral ulcers of Behçet's syndrome". Clinical and Experimental Rheumatology 24 (5 Suppl 42): S83-6.

19. Uchida, Y. (2011). "Rhizoctonia Solani" Knowledge Master. Web. 04 Oct JaniceUchilda Knowledge Master.

20. Vogt, R.L. and Dippold, L. (2005). "Escherichia coli O157:H7 outbreak associated with consumption of ground beef". Public Health Rep 120 (2): 174-8.

21. Whitt, D. and Salyers, A. (2002). "14". Bacterial Pathogenesis: A Molecular Approach (2nd ed.). USA: ASM Press.

22. Yang, F. (2005). "Genome dynamics and diversity of Shigella species, the etiologic agents of bacillary dysentery". Nucleic Acids Research 33 (19): 6445-6458.

23. Zheng, R.Y.; Chen, G.Q.; Huang, H. \& Liu, X.Y. (2007). "A monograph of Rhizopus". Sydowia 59 (2): 273-372. 